\title{
Dampak Peralihan Massal Transportasi Jalan Raya ke Mobil Listrik
}

\section{Edwaren Liun*}

Pusat Kajian Sistem Energi Nuklir, BATAN, Jl. Kuningan Barat, Jakarta Selatan

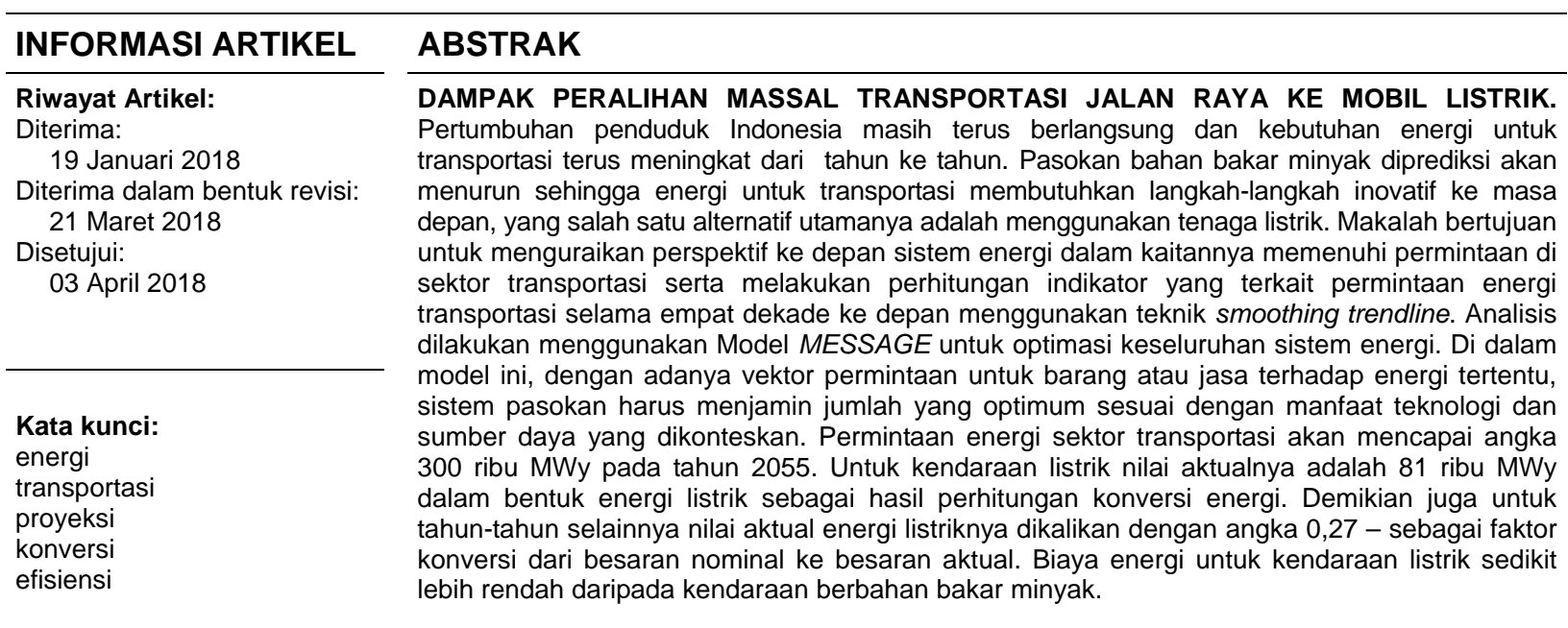

\begin{abstract}
THE IMPACT OF MASS TRANSFER OF THE ROAD TRANSPORTATION TO THE ELECTRIC CAR. Indonesia's population is still growths continuously, and energy demand for transportation continues to increase from year to year. The supply of petroleum fuel is predicted to decrease so that energy for transportation requires innovative steps into the future, and one of the alternatives is using electric power for road transport vehicles. The paper aims to describe the forward-looking perspective of energy systems in corresponding to meet demand in the transportation sector and forecasting related indicators to transportation energy demand over the next four decades using smoothing trendline techniques. The analysis here uses the MESSAGE Model for the overall optimization of the energy system. In this model, in the presence of a demand vector for goods or services of a given energy, the supply must be kept to an amount appropriate to the utilization of contemplated technology and resources. Transportation energy demand will reach 300 thousand MWy of energy depicted in 2055. For electric vehicles actually is 81 thousand MWy in the form of electricity energy as a result of energy conversion calculations. Similarly for years apart from the truth. With a value of 0.27 - as a conversion factor of the nominal amount to the actual magnitude. In terms of energy costs, electric vehicles with thin difference are cheaper than oil-fueled vehicles.
\end{abstract}

Keywords: energy, transportation, projection, conversion, efficiency

(c) 2017 Jurnal Pengembangan Energi Nuklir. All rights reserved

\section{PENDAHULUAN}

Pertumbuhan permintaan energi didorong oleh pertumbuhan penduduk, pertumbuhan GDP, dan perubahan gaya hidup. Penduduk Indonesia mengalami pertumbuhan GDP per kapita rata-rata sebesar 5,45\% per tahun dari tahun 2000 sampai 2013[1]. Di lain pihak produksi minyak Indonesia mengalami penurunan secara signifikan meskipun produksi gas masih mengalami kenaikan selama satu dasawarsa terakhir [2].

*Penulis korespondensi.

E-mail: edwaren@batan.go.id
Energi merupakan substansi dasar bagi pembangunan sosial dan memainkan peran penting sebagai faktor lingkungan dalam kelangsungan hidup dan perkembangan sosial manusia[3]. Permintaan energi juga mendapat pengaruh dari perkembangan komposisi teknologi[4]. Penggunaan bahan bakar yang berasal dari minyak bumi hingga kini belum tersubstitusikan dengan bahan atau sumber energi dari jenis lain. Salah satu sektor yang sangat tergantung pada bahan bakar minyak 
adalah transportasi[5]. Pertumbuhan jumlah kendaraan dari tahun ke tahun cukup tinggi. Antara tahun 2000-2010 jumlah kendaraan meningkat dari 18,98 juta unit pada tahun 2000 menjadi 77,13 juta unit pada tahun 2010 atau tumbuh rata-rata $15,1 \%$ per tahun. Saat ini pangsa terbesar adalah penggunaan sepeda motor yang mencapai $79 \%$ dari total jumlah kendaraan bermotor [6].

Di samping sektor transportasi, sektor industri juga tumbuh cukup tinggi[7] ditandai dengan pangsanya yang bertahan pada kisaran antara 41-42\% antara tahun 2010 sampai 2013[8]. Sektor industri dapat didukung oleh berbagai jenis energi, sedangkan jenis energi untuk sektor transportasi sangat terbatas. Terlepas dari kenyataan bahwa sektor transportasi memegang peranan penting dalam menentukan permintaan energi nasional, penyediaan energi untuk transportasi memerlukan perhatian yang lebih khusus[9]. Hal ini disebabkan karena kompleksitas dalam urusan transportasi, kurangnya jenis energi yang dapat mendukung, serta keniscayaan bahwa jenis energi yang mendukung sektor transportasi selama ini akan mengalami penyusutan produksi dalam beberapa dasawarsa mendatang. Sebagian besar sektor transportasi di seluruh dunia menggunakan bahan bakar yang berasal dari minyak bumi dengan pertumbuhan rata-rata sebesar $2,5 \%$ per tahun [6][10].

Makalah bertujuan untuk menguraikan perspektif ke depan sistem energi dalam kaitannya untuk memenuhi permintaan di sektor transportasi serta meramalkan indikator yang terkait permintaan energi transportasi selama empat dekade ke depan menggunakan teknik exponential smoothing. Tujuan kedua adalah untuk merespon proyeksi permintaan energi pada sektor transportasi untuk empat dekade ke depan. Hasilnya diharapkan dapat membantu rencana kebijakan energi dalam memahami implikasi perubahan terkait rencana pengembangan produksi energi untuk sektor transportasi masa depan[11].

Kajian dilakukan dengan analisis kuantitatif kebutuhan energi dari data historis hingga proyeksi ke depan atas beberapa ketentuan dan kondisi yang berpengaruh seperti penurunan produksi minyak bumi dan semakin berkembangnya teknologi penyimpanan energi baterai. Hasil yang diperoleh adalah bahwa dalam beberapa dasawarsa mendatang opsi yang paling potensial dalam memenuhi kebutuhan energi untuk transportasi darat, baik transportasi massal maupun pribadi, adalah energi listrik.

\section{METODOLOGI}

Analisis sistem energi di sini menggunakan model Model for Energy Supply Strategy Alternatives and their General Environmental Impacts yang disingkat dengan sebutan MESSAGE. Di dalam model ini, dengan adanya vektor permintaan untuk barang atau jasa terhadap energi tertentu, pasokan menjamin jumlah yang memadai dengan memanfaatkan teknologi dan sumber daya yang dikonteskan. Model MESSAGE memungkinkan pemodelan semua tahapan aliran energi dari penawaran ke permintaan, yang umumnya disebut sebagai supply chain, sedangkan setiap tahapan dalam aliran energi disebut energy level. Elastisitas harga-harga dapat diinterpretasikan sebagai elastisitas jangka pendek yang mengakibatkan berkurangnya permintaan karena kenaikan harga yang tajam (keadaan ini terkait dengan tingkat harga referensi) [12].

Analisis yang ditekankan di sini adalah permintaan energi di sektor transportasi mengingat bahwa sektor ini paling rawan akan kelangkaan energi. Faktor yang mempengaruhi permintaan energi Indonesia diselidiki dengan menerapkan analisis koefisien aliran sistem energi. Faktor paling utama yang mempengaruhi demand tahunan energi seperti GDP [13], penduduk, struktur ekonomi, tingkat urbanisasi dan struktur energi sebagai input dari model yang dapat berupa bentuk linier, eksponensial dan pangkat. Model kemudian dikembangkan dengan mengadopsi input data yang disesuaikan. Permintaan energi masa depan diproyeksikan berdasarkan data historis antara tahun 2010-2015. Makalah ini disusun berdasarkan informasi yang berasal dari literatur dan pengolahan data dengan pemodelan sistem energi wilayah Indonesia yang terdiri dari dua bagian, yaitu Bagian 1 (Sumatera, Jawa, Madura dan Bali) dan Bagian 2 (Wilayah selainnya).

Aliran energi dimodelkan sesuai alur variabel aktifitas teknologi konversi yang 
berbeda dan ekstraksi sumberdaya, serta variabel impor dan ekspor di dalam neraca energi. Sedangkan permintaan energi juga dimodelkan sebagai bagian dari kendala neraca energi; yaitu pada sektor demand dan mendefinisikan jumlah yang harus disuplai oleh teknologi di dalam kendala ini. Faktor ini harus menjadi faktor penentu untuk konsumsi energi transportasi[11].

Permintaan energi dipengaruhi oleh lima faktor, yaitu jumlah penduduk, GDP, pertumbuhan industri, urbanisasi dan perubahan gaya hidup masyarakat. Analisis pasokan energi ini menggunakan perhitungan koefisien statistik yang merangkum total konsumsi energi, sedangkan analisis permintaan energi Indonesia menerapkan analisis alur dan koefisien atas dasar algoritma hybrid[12]. Koefisien di sini terdiri atas tiga bentuk model (model linear, model eksponensial dan polinomial berpangkat hingga 3) yang dioptimalkan berdasarkan data dasarnya.

Untuk mendapatkan kurva prediksi kombinasi dari tiga bentuk, metode koefisien arah diterapkan untuk mendapatkan bobot kombinasinya. Permintaan energi Indonesia telah mencapai 4,48 milyar TCE pada tahun 2015[14]. Sementara konsumsi energi untuk sektor transportasi sejak tahun 2000 hingga 2013 menunjukkan kenaikan relatif tinggi, yakni sebesar 6,86\% per tahun. Jika tren laju pertumbuhan seperti ini berlanjut maka pada tahun 2025 konsumsi energi untuk sektor transportasi akan menjadi sekitar 510 juta SBM per tahun, meningkat 3,7 kali dari konsumsi tahun 2000[15].

Dalam model MESSAGE perumusan umum model pemrograman linier dinamis dengan mixed integer menyiratkan bahwa semua hubungan yang mendefinisikan struktur model diberikan sebagai constrain linier antara variabel kontinyu. Variabel model tersebut dinyatakan dalam "lajur" dan "baris" persamaan. Nomenklaturnya berasal dari notasi yang biasa digunakan untuk menuliskan model linear dalam bentuk matriks. Variabel (kolom) dari MESSAGE dikelompokkan menjadi tiga kategori[12]:

1. Variabel aliran energi mewakili kuantitas aliran energi tahunan. Satuan yang biasa digunakan adalah MWy atau GWy untuk wilayah yang lebih besar,
2. Variabel daya mewakili kapasitas produksi teknologi (unit biasa: MW atau GW), dan

3. Stock-pile mewakili kuantitas bahan bakar yang terakumulasi pada titik tertentu seiring waktu satuan yang biasanya dalam MWy atau GWy).

Teknologi dapat memiliki lebih dari satu input atau output pada sektor demand, sedangkan variabel aktivitas dan keterbatasan kapasitas akan dihasilkan secara default dan terpisah untuk masing-masing sektor demand. Ini dapat diubah dengan mendefinisikan pola produksi sepanjang daerah beban[16]. Jika pola produksi dibiarkan bebas, maka produksi untuk memenuhi masing-masing sektor demand kemungkinan menjadi terbatas dalam kaitannya dengan kapasitas terpasang. Secara terpisah kebutuhan akan kapasitas pasokan untuk masing-masing sektor ditentukan oleh aktivitas di wilayah beban. Faktor pembangkit dinyatakan sebagai fraksi sistem yang beroperasi dalam mode operasi puncak (secara umum ini adalah faktor ketersediaan). Berapa kali perawatan atau berapa kali operasi minimum dimasukkan dengan menggunakan hubungan tambahan yang diperlukan[12].

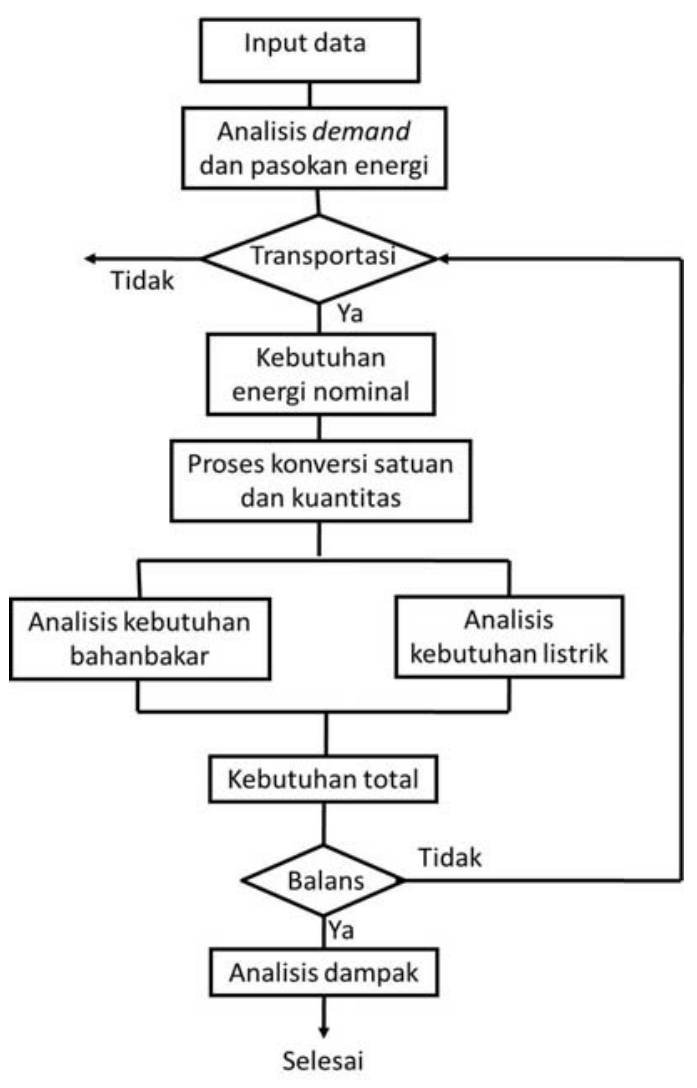

Gambar 1. Bagan Alir Proses Analisis dan Proyeksi Kebutuhan Energi Sektor Transportasi 
Gambar 1 menunjukkan bagan alir yang diterapkan dalam proses analisis dampak peralihan massal transportasi jalan raya ke mobil listrik.

Dalam analisis ini, pendekatan model konsumsi energi di sektor transportasi dikembangkan berdasarkan teknik exponential smoothing atas data historis yang tersedia. Model menguraikan aspek pendorong perubahan konsumsi bahan bakar, khususnya untuk sektor transportasi.

Pada studi ini proyeksi untuk penggunaan akhir energi pada setiap sektor dihitung terlebih dahulu, dan setiap variabel dipertimbangkan berdasarkan perbandingan dan indikator yang sesuai sampai batas tertentu. Tabel 1 adalah hasil proyeksi berdasarkan data historis yang digunakan untuk memproyeksi permintaan energi per sektor[15].

\section{HASIL DAN PEMBAHASAN}

Tabel 1. Proyeksi Kebutuhan Energi Hingga Tahun 2055

\begin{tabular}{cc}
\hline Tahun & MWy \\
\hline 2015 & 320,860 \\
2020 & 333,764 \\
2025 & 391,346 \\
2030 & 468,445 \\
2035 & 554,898 \\
2040 & 652,792 \\
2045 & 775,005 \\
2050 & 925,296 \\
2055 & $1,107,769$ \\
\hline
\end{tabular}

Ref: Diolah dari[15]

Energi yang digunakan untuk sektor transportasi saat ini menunjukkan kecenderungan yang rawan terhadap kelangkaan. Permintaan dan pertumbuhan permintaan energi untuk sektor tranportasi di Indonesia hampir sama dengan industri. Namun permintaan jenis energi di sektor transportasi terbatas hanya bertumpu pada BBM yang membuat sektor ini paling sensitif terhadap isu kelangkaan energi[17].

Dengan memperhitungkan sumber energi biomassa tradisional, total konsumsi energi nasional diproyeksikan meningkat menjadi 298 juta TOE pada tahun 2025 dan 893 juta TOE pada tahun 2050 atau mengalami kenaikan rata-rata sebesar $4,9 \%$ per tahun selama periode 2013-2025 dan 4,5\% per tahun pada periode 2025-2055 untuk skenario $\mathrm{BaU}$ (Business as Usual). Sedangkan untuk skenario KEN (Kebijakan Energi Nasional), pada tahun 2025 konsumsi akan meningkat menjadi 253 juta TOE atau tumbuh sebesar $3,4 \%$ per tahun atau mengalami pertumbuhan sebesar 3,5\% pada periode 2025-2050[18]. Namun bila dibandingkan dengan pertumbuhan kebutuhan transportasi angka pertumbuhan tersebut tidaklah memadai.

Sektor transportasi akan mengalami kelangkaan bila hanya bertumpu pada bahan bakar konvensional dan biomassa. Tidak seperti sektor pengguna lainnya, sektor transportasi sangat tergantung pada energi atau bahan tertentu, karakteristik kemanfaatan dan karakteristik sistem.

Asumsi kunci dalam analisis sistem energi ini adalah parameter energi yang tepat untuk pasokan energi primer, analisis penggunaan akhir dan kegiatan ekonomi. Untuk perkayaan wawasan ekonomi, Percebois[19] menyarankan pada tahun 1979 bahwa intensitas energi metrik (yaitu konsumsi energi relatif terhadap PDB) lebih baik dilakukan pada tahap output energi. Hal ini memungkinkan untuk menganalisis perubahan struktural dalam pasokan energi dan menempatkan analisis untuk memenuhi tingkat kebutuhan[19].

Pada skala besar, pedoman strategis mengharuskan pembuat kebijakan dan manajemen energi untuk mempertimbangkan penerapan pendekatan demand side di sektor demand. Namun, pengetahuan tentang aspek kebutuhan terbatas, sehingga pekerjaan menganalisis dapat menjadi lebih rumit. Untuk mengatasi masalah ini, para analis menggunakan perangkat studi manajemen energi seperti yang telah dikembangkan oleh berbagai negara dan instansi di dunia, seperti MAED, WASP, ENPEP, LEAP, MESSAGE, dan sebagainya, yang menggabungkan fitur alam dan manusia dan menyebabkan interdisipliner masalah[20].

Tujuan penelitian ini adalah untuk memprediksi kebutuhan energi listrik ke depan berkenaan dengan potensi peralihan konsumsi energi sektor transportasi dari sumber energi berbasis minyak ke sumber berbasis listrik. 


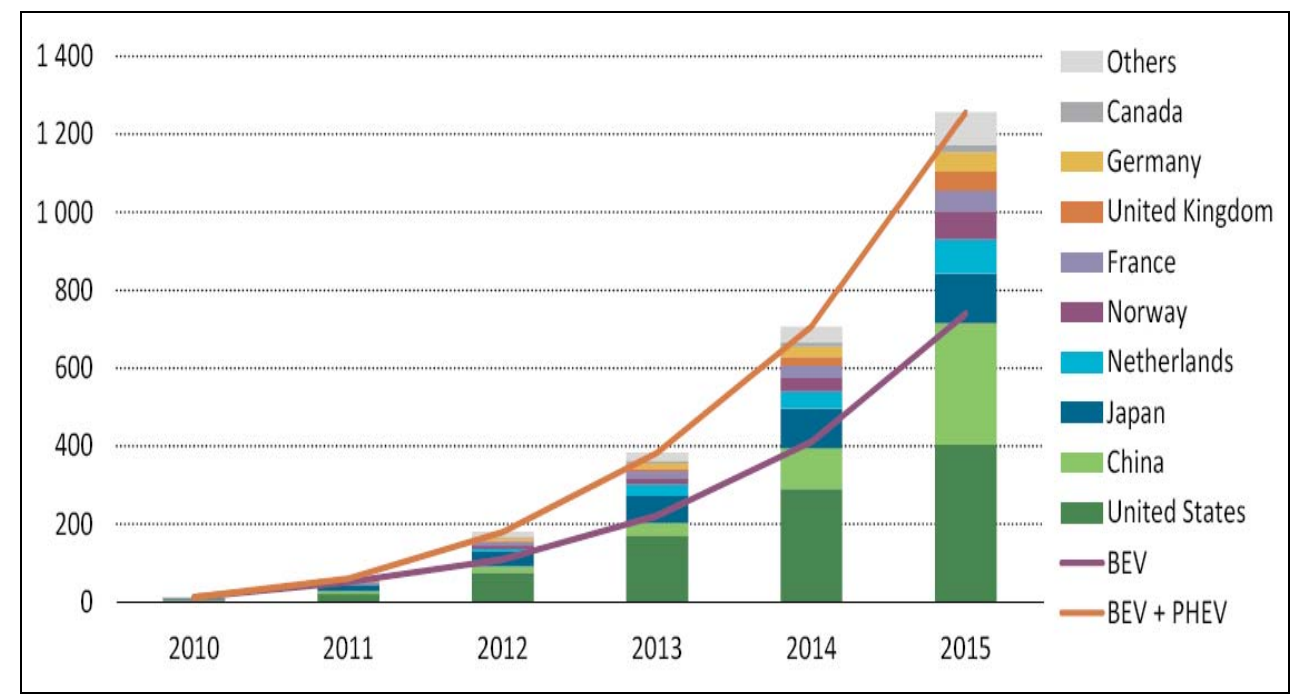

Gambar 2. Statistik Pasokan Mobil Listrik di Dunia (Dalam Ribu Unit) [20]

Perkembangan penggunaan mobil listrik selama ini terindikasi pada stoknya yang telah berkembang sejak 2010, dengan serapan mobil baterai telah menyusul serapan mobil hibrida menjadi $80 \%$ mobil listrik berada di Amerika Serikat, China, Jepang, Belanda dan Norwegia[21].

Konsumsi energi listrik untuk sektor transportasi akan melibatkan kebutuhan berbagai aspek daya listrik yang tersedia pada sistem jaringan, seperti keandalan pasokan, dukungan infrastruktur stasiun pengisian baterai dan harga yang terjangkau untuk masyarakat luas. Gambar 2 menunjukkan gambaran data historis pasokan mobil listrik di dunia yang cenderung meningkat secara eksponensial dari tahun ke tahun.

Cadangan energi likuid Indonesia ke depan lebih mengandalkan gas alam. Produksi rata-rata gas Indonesia pada tahun 2012, meskipun sedikit mengalami penurunan dibanding dua tahun sebelumnya, adalah 8.412 juta standard cubic feet per day (mmscfd) (TECP, 2012) menduduki peringkat 11 di dunia selama tahun 2012 (OPEC, 2012). Produksi pada tingkat tersebut disangga oleh cadangan terbukti (seluruh lapangan, aktif dan non-aktif) sebesar 100,34 triliun standard cubic feet (SCF) berada pada peringkat ke 13 di dunia. Meskipun angka cadangan tersebut hanya sekitar $1,5 \%$ saja dari total cadangan terbukti dunia (6.793 triliun SCF per 1 Jan 2012) tetapi angka tersebut diperkirakan akan meningkat seiring dengan pengembangan lapangan yang telah ditemukan[22].

Sektor energi mempunyai peranan penting bagi peningkatan kegiatan ekonomi dan ketahanan nasional, sehingga pengelolaan energi yang meliputi penyediaan, pemanfaatan dan pengusahaan harus dilaksanakan secara terencana, ekonomis, terintegrasi dan berkelanjutan[6]. Subsidi energi sangat membebani ekonomi nasional dan membuat pembangunan fisik dan sosial terganggu. Untuk itu, mulai akhir Desember 2014, subsidi atas bensin (premium) dihapus/dikurangi dan subsidi minyak solar untuk kendaraan bermotor bersifat tetap sebesar Rp. 1.000 per liter. Hal ini ditandai dengan ditetapkannya Perpres No. 191/2014 yang ditindaklanjuti dengan Permen ESDM No. 04/2015 dan Kepmen ESDM No. 0135/K/12/MEM/2015[7].

Kebijakan subsidi listrik juga telah dikurangi dengan tidak diberikannya lagi subsidi listrik terhadap 12 golongan tarif tenaga listrik sebagaimana diatur dalam Permen ESDM 31/2014. Keduabelas golongan tarif tenaga listrik tersebut mencakup untuk keperluan rumah tangga ( $\geq 1.300 \mathrm{VA}$ ), bisnis $(\geq 6.600 \mathrm{VA})$, industri $(\geq 200 \mathrm{kVA})$, kantor pemerintah $(\geq 6.600 \mathrm{VA})$, penerangan jalan umum tegangan rendah, dan layanan khusus. Penghapusan subsidi BBM dan listrik tersebut mendorong menurunnya subsidi energi dari 315 triliun rupiah pada tahun 2014 menjadi 119 trilliun rupiah pada tahun 2015 yang 


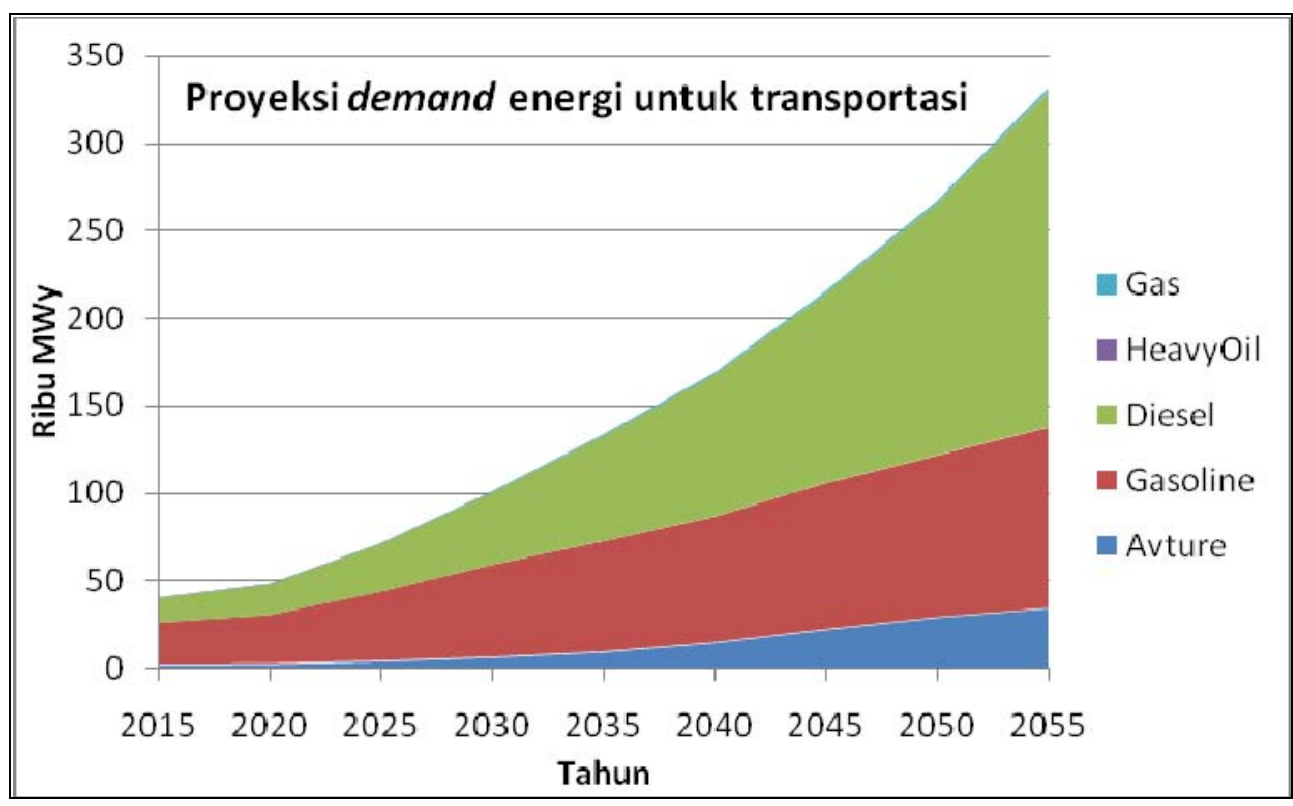

Gambar 3. Proyeksi Permintaan Energi untuk Transportasi

digunakan untuk pembangunan infrastruktur dan sosial[6].

Data historis konsumsi energi menunjukkan peningkatan dari 139 juta SBM pada tahun 2000 menjadi 256 juta SBM pada tahun 2010, atau meningkat dengan laju partumbuhan rata-rata 6,2\% per tahun[7][15]. Sedangkan proyeksi konsumsi energi di sektor transportasi untuk kurun waktu 2015-2055 ditunjukkan pada Gambar 3. Pertumbuhan terbesar adalah pada penggunaan avtur/avgas dengan laju partumbuhan $11,3 \%$ per tahun, diikuti oleh listrik $(7,2 \%)$, bensin $(6,8 \%)$, dan minyak solar/diesel (5,0\%). Penggunaan Bahan Bakar Gas (BBG), minyak bakar dan minyak tanah mengalami penurunan. Meskipun penggunaan BBG terus dikembangkan namun karena infrastruktur pasokannya belum memadai, sehingga sampai saat ini pengembangan BBG untuk transportasi masih banyak mengalami kendala[9].

Berdasarkan data historis dan pertumbuhan permintaan energi dalam bentuk bahan bakar di sektor transportasi, maka permintaan energi dalam bentuk bahan bakar dan energi listrik untuk sektor transportasi diproyeksikan hingga pertengahan abad ke-21 seperti ditunjukkan pada Gambar 4. Asumsi ini didasarkan pada fenomena global yang berkenaan dengan tren pertumbuhan kendaraan bertenaga listrik (Electric Vehicle,
EV) dan potensi penurunan produksi minyak bumi dunia.

Dari sisi penggunaan energi, mobil listrik juga lebih menguntungkan dengan kisaran efisiensi sebesar 90\%[23]. Namun karena faktor efisiensi pada pembangkit listrik hingga sampai ke pengguna berkisar sekitar 25-30\%, maka total efisiensi energi pada mobil listrik berkisar antara 22,5-27\%. Angka ini masih jauh lebih baik daripada kendaraan yang menggunakan mesin pembakaran dalam (Internal Combustion Engine, ICE) dengan efisiensi sekitar $20 \%$.

Untuk kendaraan listrik, faktor pengisian baterai adalah penting. Pengisian juga dapat terjadi dari pengereman regeneratif. Daya pengereman regeneratif dapat mencapai level daya ratusan watt hingga tingkat kilowatt pada kendaraan kecil. Batasan keselamatan juga penting diterapkan untuk menjamin pengoperasian baterai yang aman. Pengereman mekanis biasanya digunakan untuk membantu pengereman regeneratif pada EV, sebagai langkah pelengkap dan aman[24]. Pengereman regeneratif juga merupakan upaya konservasi terhadap energi yang hilang [19].

Pada kendaraan listrik nilai energi merupakan kuantitas input yang bila dikuantifikasi sebagai energi output $\left(\mathrm{E}_{\mathrm{O}}\right)$ akan menjadi energi yang berguna pada kendaraan dengan mengikuti formula sebagai berikut: 


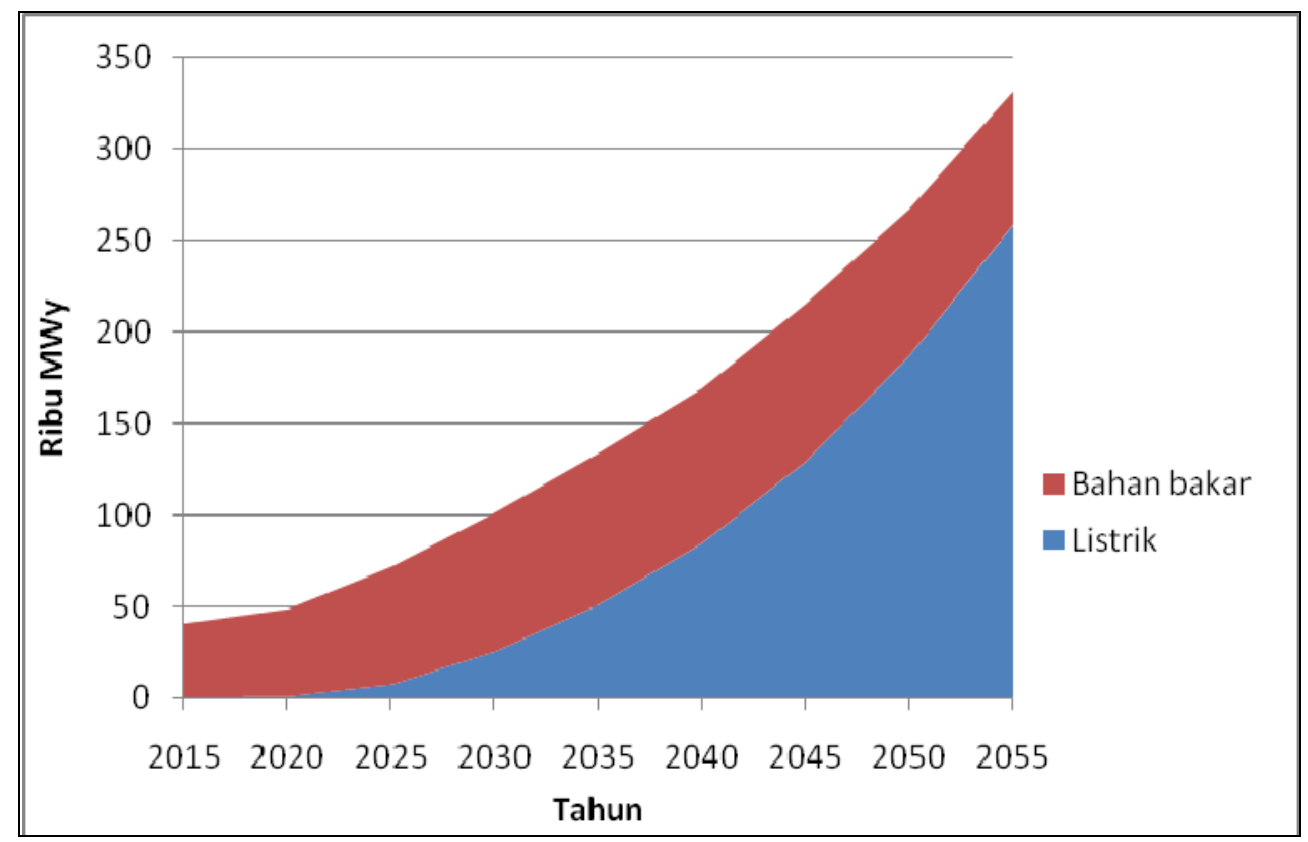

Gambar 4. Proyeksi Rasio Kontribusi Energi di Sektor Transportasi dalam Nilai Nominal (Setara Bahan Bakar)

$E_{O}=\frac{\eta_{G}}{\eta_{V}} \times E_{I}$

Keterangan:

$\mathrm{E}_{\mathrm{O}}=$ Energi output setara berupa energi listrik berguna yang dibutuhkan

$\mathrm{E}_{\mathrm{I}}=$ Energi input setara energi berupa bahan bakar yang dibutuhkan

$n_{\mathrm{G}}=$ Efisensi total sistem kelistrikan pada sisi pasokan, berkisar $27 \%$

$\eta_{\mathrm{V}}=$ Efisensi total penggunaan energi listrik pada kendaraan, berkisar $90 \%$

Dengan demikian perbandingan kebutuhan pasokan energi listrik terhadap energi dalam bentuk bahan bakar yang dibutuhkan untuk memenuhi permintaan transportasi berkisar $27 \% / 90 \%=30 \%$. Sedangkan efisiensi total sistem energi pada kendaraan listrik berkisar $0,27 \times 0,9=24,3 \%$, atau $4 \%$ lebih tinggi daripada keseluruhan sistem kendaraan pembakaran dalam (ICE). Dengan kata lain perbandingan rata-rata konsumsi energi total antara mobil listrik terhadap mobil pembakaran dalam adalah sekitar $82 \%$ pada nilai nominal (dalam bentuk energi primer).

Karena nilai yang ditunjukkan pada Gambar 4 di atas adalah kuantitas nominal pada sistem konversi energi, maka jika energi yang digunakan adalah energi listrik, maka arsiran berwarna biru (indikator listrik) harus dikonversi dengan mengalikannya dengan angka 0,27, yaitu sebagai efisiensi dari kendaraan pembakaran dalam (24\%) dibagi efisiensi transmisi dan distribusi listrik (90\%). Jadi angka kebutuhan 260 ribu MWy pada tahun 2055 untuk kendaraan listrik, nilai aktualnya adalah 70 ribu MWy dalam bentuk listrik. Demikian juga untuk tahun-tahun selainnya nilai aktual energi listriknya adalah sebesar nilai nominal dikalikan dengan angka 0,27. Area berwarna biru pada Gambar 4 adalah capaian yang dapat dipikul oleh energi listrik pada sektor transportasi. Sementara penggunaan untuk pesawat terbang dan kapal laut diasumsikan tetap menggunakan bahan bakar minyak.

Gambar 5 menunjukkan proyeksi perbandingan permintaan bahan bakar dan listrik untuk transportasi. Di Indonesia sektor transportasi banyak mengalami kendala sebagai penyedia sarana berupa angkutan umum yang bersifat massal, maupun prasarana berupa jalan dan sistem pendukungnya[6]. Karenanya ketergantungan terhadap bahan bakar minyak di sektor ini sangat tinggi, sehingga pemanfaatan gas dan bahan bakar nabati diharapkan dapat mengurangi ketergantungan dan subsidi sehingga dapat dimanfaatkan untuk kepentingan lain atau pembangunan infrastruktur[19]. Sistem 


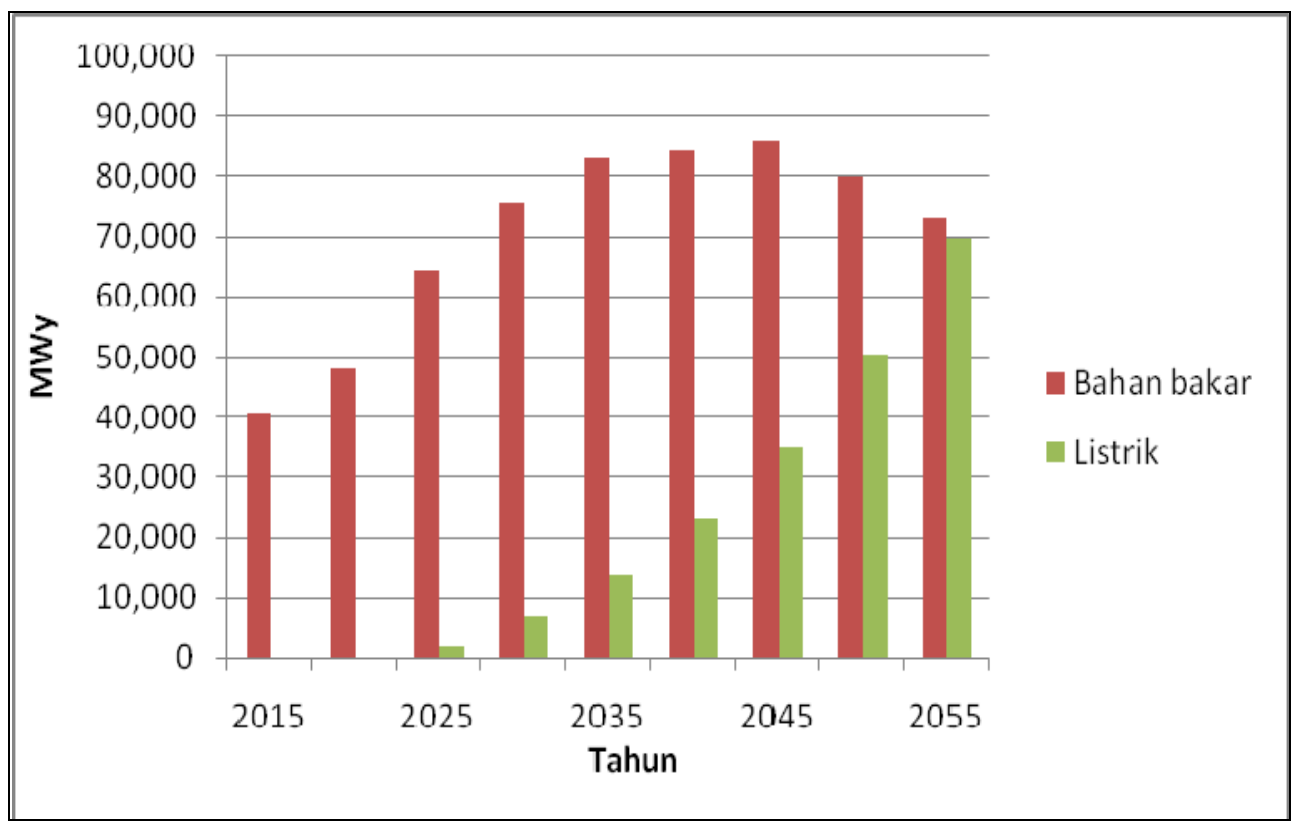

Gambar 5. Proyeksi Kebutuhan Bahan Bakar dan Listrik untuk Transportasi (Nilai Listrik adalah Aktual).

propulsi mobil listrik pada konfigurasi sebagian atau seluruh daya dan energi propulsinya dipasok oleh baterai yang ada di dalam kendaraan[25]. Mobil listrik juga perlu menangani pengereman regeneratif sehingga sisa energi kinetik kendaraan dapat dikembalikan dan disimpan dalam baterai untuk penggunaan selanjutnya[25][26].

Ada beberapa metode pengisian baterai, yaitu 1) Metode tegangan konstan, mengisi baterai pada voltase konstan. Metode ini cocok untuk semua jenis baterai dan memungkinkan untuk skema pengisian yang paling sederhana. Arus pengisian baterai bervariasi sepanjang proses pengisian. Arus pengisian dapat berukuran besar pada tahap awal dan secara bertahap turun menjadi nol saat baterai terisi penuh. Kekurangan dalam metode ini adalah persyaratan daya yang sangat tinggi pada tahap awal pengisian, yang tidak tersedia untuk sebagian besar struktur perumahan dan tempat parkir. 2) Arus konstan pada pengisian ini, voltase pengisian daya pada baterai dikendalikan pada arus konstan. Source of Charge (SOC) akan meningkat secara linear versus waktu untuk metode arus konstan[27], 3) Kombinasi tegangan konstan dan metode arus konstan. Selama proses pengisian baterai, biasanya kedua metode tersebut akan digunakan. Kemudian, baterai dinyalakan untuk mengisi baterai dengan arus konstan hingga nilai yang lebih tinggi. Bila voltase baterai mencapai titik ambang tertentu, pengisian akan berubah menjadi tegangan konstan. Biaya voltase konstan dapat digunakan untuk menjaga voltase baterai sesudahnya jika suplai pengisian Direct Current (DC) masih tersedia[25].

Penggunaan mobil bertenaga listrik lebih hemat dari segi biaya. Harga satu liter gasoline kelas pertalite adalah Rp 7.500,-/liter yang dapat menghasilkan sekitar $3 \mathrm{kWh}$, atau Rp. 1500,-/kWh. Energi ini hasil konversi menjadi energi mekanik sebagai penggerak. Sementara harga energi listrik PLN pada daya 6.100 VA adalah 1.467,28 Rp/kWh yang tidak jauh berbeda dari mesin pembakaran dalam. Dari segi biaya perbedaan tipis ini tidak berpengaruh signifikan, namun dari aspek ketersediaan jangka panjang, energi dari jaringan listrik akan lebih menjamin karena dapat dihasilkan dari berbagai sumber energi, termasuk energi nuklir. Peralihan sistem transportasi ke kendaraan listrik memberikan banyak dampak positif. Berbagai sumber energi yang selama ini hanya dapat memikul beban stasioner seperti nuklir yang dapat membangkit listrik dalam skala besar, tenaga air, panas bumi, dan sebagainya akan dapat menjadi andalan sebagai tenaga penggerak bagi sistem transportasi secara luas.

Pasokan mobil listrik untuk beberapa negara pada tahun 2015 mencapai 1,26 juta. Angka ini melebihi 100 kali dari perkiraan 
tahun 2010, yang menembus batas 1 juta mobil listrik di jalan raya. Pada tahun 2015, Amerika Utara (sebagian besar Amerika Serikat) berkontribusi sebesar 34\%. Hampir sepertiga mobil listrik berada di Eropa, di mana Belanda menyumbang $23 \%$ dari total. Asia menyumbang $36 \%$, yang mana pada tahun 2015 satu dari empat mobil listrik berada di China, dan satu dari sepuluh berada di Jepang. Pertumbuhan persediaan mobil listrik global melampaui $77 \%$ di tahun 2015 dan $84 \%$ di tahun 2014, sedikit menurun dari periode 2011-2013, sehingga jumlah mobil listrik meningkat dua kali lipat setiap tahunnya. Pada tahun 2014-2015, kenaikan tertinggi terjadi di China, Korea, Inggris, Swedia, Norwegia, Belanda dan Jerman[21][28].

Perkembangan mobil listrik telah menjadi fenomena global di awal abad ke-21 atas beberapa alasan seperti upaya substitusi bahan bakar minyak dan peragaman sumber energi pada sektor transportasi, simplifikasi teknologi kendaraan, keamanan dan efisiensi dalam beberapa aspek berkendara. Peralihan penggunaan kendaraan dari ICE ke EV akan mengandung implikasi bahwa beban penyediaan bahan bakar minyak atau bahan bakar fosil yang berlangsung selama ini akan beralih secara gradual menjadi beban pada sektor penyediaan tenaga listrik. Pertumbuhan kebutuhan tenaga listrik akan menjadi lebih tinggi untuk menggantikan bahan bakar fosil pada sektor transportasi. Selain itu terjadi peningkatan kebutuhan untuk perluasan jaringan interkoneksi dalam memenuhi layanan bagi pengguna kendaraan.

\section{KESIMPULAN}

Analisis neraca sistem untuk optimasi pasokan energi dengan Model MESSAGE dimana salah satu fokus yang ditekankan dalam makalah ini adalah sektor transportasi. Pengembangan sistem energi untuk sektor transportasi tampak mengarah pada upaya pengembangan kendaraan berbasis listrik karena alasan teknologi masalah ketersediaan bahan bakar minyak. Dampak utama dari peralihan massal transportasi jalan raya ke mobil listrik adalah tejadinya peningkatan kebutuhan energi listrik dalam skala besar. Namun karena energi listrik dapat dibangkitkan dari berbagai sumber energi termasuk nuklir, maka hal tersebut meringankan beban penyediaan bahan bakar minyak yang semakin langka untuk sektor transportasi.

Hasil perhitungan yang terkait dengan nilai kesetaraan pada sektor transportasi menunjukkan nilai kuantitas energi dalam satuan dasar, asli dan setara listrik, yaitu efisiensi sebesar $24,3 \%$, atau $4 \%$ lebih tinggi daripada kendaraan pembakaran dalam untuk keseluruhan sistem. Sedangkan konsumsi energi untuk menghasilkan tenaga yang sama dengan sistem ICE hanya sekitar $82 \%$, atau lebih hemat $18 \%$.

Dari segi ketersediaan energi, mobil listrik dapat menggunakan semua jenis energi yang dapat dikonversi menjadi energi listrik secara terpusat. Beberapa jenis energi paling potensial sebagai pembangkit listrik seperti nuklir, tenaga air, panas bumi dan sebagainya dapat berkontribusi sebagai penggerak roda sistem transportasi secara luas. Kekhawatiran akan kelangkaan bahan bakar minyak juga akan teratasi dengan sendirinya.

\section{DAFTAR ACUAN}

[1] BPS. 2013. Perkembangan Beberapa Indikator Utama Sosial-Ekonomi Indonesia. Badan Pusat Statistik

[2] B. Widarsono, "Cadangan dan produksi gas bumi nasional: Sebuah analisis atas potensi dan tantangannya," Lembaran Publikasi. Minyak. dan Gas Bumi, vol. 47, no.3, pp. 115-126, Desember 2013.

[3] Y. Shiwei, Z. Kejun, and Z. Xian, "Energy demand projection of China using a path-coefficient analysis and PSO-GA approach," Energy Conversion Management., vol. 53, no. 1, pp. 142153, January 2012.

[4] T-B. Oriol, P. O. G. Brian, J. Eric, et al., "Transport energy demand in Andorra. Assessing private car futures through sensitivity and scenario analysis," Energy Policy, vol. 96, pp. 7892, September 2016.

[5] T. Chatterton, J. Anable, S. Cairns, and R. E. Wilson, "Financial Implications of Car Ownership and Use: A distributional analysis based on observed spatial variance considering income and domestic energy costs," Transport Policy, vol. 65, pp. 30-39, July 2018.

[6] BPPT. 2016. Outlook Energi Indonesia 2016. Badan Pengkajian dan Penerapan Teknologi. Jakarta

[7] S. Agus, "Permasalahan dan Kebijakan Energi Saat Ini," dalam Konferensi Peluncuran Buku Outlook Energi Indonesia 2014 \& Seminar Bersama BPPT dan BKK-PII, Jakarta, ID, 2014, pp. 9-16. 
[8] BPS. 2011. Indonesia Economic Growth 2010. Badan Pusat Statistik. Jakarta

[9] S. Agus, "Data Historis Konsumsi Energi dan Proyeksi Permintaan-Penyediaan Energi di Sektor Transportasi," dalam Konferensi Prosiding Seminar dan Peluncuran Buku Outlook Energi Indonesia 2012, Jakarta, ID, 2012, pp. 24-29.

[10] IEA. November 2012. World Energy Outlook 2012. Volume 23. International Energy Agency

[11] P. David, A. N. Stuart, S. W. Gavin, et al., "Optimum community energy storage system for demand load shifting," Applied Energy, vol. 174, pp. 130-143, July 2016.

[12] IAEA. June 2007. Model for Energy Supply Strategy Alternatives. International Atomic Energy Agency. Vienna, Austria

[13] A. Ünler, "Improvement of energy demand forecasts using swarm intelligence: The case of Turkey with projections to 2025," Energy Policy, vol. 36, issue 6, pp. 1937-1944, June 2008.

[14] Pusat Data dan Informasi ESDM. 2012. Kajian Supply Demand Energi. Kementerian Energi dan Sumber Daya Mineral

[15] ESDM. 2016. Handbook of Indonesia's Energy Economy Statistics 2016. Volume 45. Nomor 12. Kementerian Energi dan Sumber Daya Mineral

[16] L. Xavier, M. L. José, and L-O. Xiral, "A metaanalysis on the price elasticity of energy demand," Energy Policy, vol. 102, pp. 549-568, March 2017.

[17] W. Xinkai, F. David, C. Alfredo, et al., "Electric vehicles' energy consumption measurement and estimation," Transportation Research Part D: Transport and Environment, vol. 34, pp. 52-67, January 2015.
[18] ESDM. April 2015. Rencana Umum Ketenagalistrikan Nasional 2015-2034. Kementerian Energi dan Sumber Daya Mineral.

[19] BPPT. 2014. Indonesia Energy Outlook 2014. Badan Pengkajian dan Penerapan Teknologi. Jakarta

[20] S. R. W. Alwi, J. J. Klemes, and P. S. Varbanov, "Cleaner energy planning, management and technologies: Perspectives of supply-demand side and end-of-pipe management," Journal of Cleaner Production, vol. 136, part B, pp. 1-13, November 2016

[21] IEA. 2016. Global EV Outlook 2016 - Beyond one million electric cars. International Energy Agency

[22] Y. Huang, Y. J. Bor, and C. Y. Peng, "The longterm forecast of Taiwan's energy supply and demand: LEAP model application," Energy Policy, vol. 39, issue 11, pp. 6790-6803, November 2011.

[23] L. Liang, W. Xiangyu, and S. Jian, "Fuel consumption optimization for smart hybrid electric vehicle during a car-following process," Mechanical System Signal Processing, vol. 87, part B, pp. 17-29, March 2017.

[24] B. Zeina, A. J. Samih, and K. Imad, "Modeling and simulation of series DC motors in electric car," Energy Procedia, vol. 50, pp. 460-470, 2014.

[25] K. Young, C. Wang, L. Y. Wang, and K. Strunz. 2013. Electric Vehicle Integration into Modern Power Networks

[26] M. Sang-Jeun and K. Jin-O, "Balanced charging strategies for electric vehicles on power systems," Applied Energy, vol. 189, pp. 44-54, March 2017.

[27] World Bank Group. 2017. World Development Indicators 2017. World Bank Group 